medRxiv preprint doi: https://doi.org/10.1101/2022.01.03.22268684; this version posted January 5, 2022. The copyright holder for this preprint (which was not certified by peer review) is the author/funder, who has granted medRxiv a license to display the preprint in perpetuity. It is made available under a CC-BY-NC 4.0 International license.

\title{
1 Burden of SARS-CoV-2 and protection from symptomatic second infection in children
}

2 John Kubale, $\mathrm{PhD}^{1^{*}} ;$ Angel Balmaseda, $\mathrm{MD}^{2^{*}} ; \mathrm{MD}$, Aaron M Frutos, $\mathrm{MPH}^{1}$; Nery Sanchez, $\mathrm{MD}^{3,4}$; Miguel

3 Plazaola, $\mathrm{MD}^{3}$; Sergio Ojeda, $\mathrm{MD}^{3,4}$; Saira Saborio, $\mathrm{MS}^{2,3}$; Roger Lopez, $\mathrm{MPH}^{2,3}$; Carlos Barilla, $\mathrm{BA}^{2}$; Gerald

4 Vasquez, $\mathrm{BS}^{2}$; Hanny Moreira, $\mathrm{BS}^{2}$; Anna Gajewski, $\mathrm{MPH}^{3}$; Lora Campredon, $\mathrm{MPH}^{1}$; Hannah Maier, $\mathrm{PhD}^{1}$;

5 Mahboob Chowdhury, $\mathrm{PhD}^{1}$; Cristhiam Cerpas, $\mathrm{BS}^{2,3}$; Eva Harris, $\mathrm{PhD}^{5}$; Guillermina Kuan, $\mathrm{MD}^{3,4}$; Aubree

6 Gordon, $\mathrm{PhD}^{1}$

$7 \quad$ *Authors contributed equally.

$8{ }^{1}$ Department of Epidemiology, University of Michigan School of Public Health, Ann Arbor, MI, USA

$9 \quad{ }^{2}$ Centro Nacional de Diagnóstico y Referencia, Ministry of Health, Managua, Nicaragua.

$10{ }^{3}$ Sustainable Sciences Institute, Managua, Nicaragua

$11{ }^{4}$ Centro de Salud Sócrates Flores Vivas, Ministry of Health, Managua, Nicaragua

$12{ }^{5}$ Division of Infectious Diseases and Vaccinology, School of Public Health, University of California,

13 Berkeley, Berkeley, California, USA.

14

15 Corresponding author: Dr. Aubree Gordon, School of Public Health, University of Michigan, Ann Arbor, 
medRxiv preprint doi: https://doi.org/10.1101/2022.01.03.22268684; this version posted January 5, 2022. The copyright holder for this preprint (which was not certified by peer review) is the author/funder, who has granted medRxiv a license to display the preprint in perpetuity. It is made available under a CC-BY-NC 4.0 International license .

\section{Key Points}

30 Question:

31 What is the burden of COVID-19 among young children and how does protection from re-infection vary

32 with age?

\section{Findings:}

34 In this study of 1964 children aged 0-14 years children $<5$ years had the highest rates of symptomatic

35 and severe COVID-19 while also displaying greater protection against re-infection compared to children $36 \geq 10$ years.

\section{Meaning:}

38 Given their greater risk of infection and severe disease compared to older children, effective vaccines 39 against COVID-19 are urgently needed for children under 5.

40 
medRxiv preprint doi: https://doi.org/10.1101/2022.01.03.22268684; this version posted January 5, 2022. The copyright holder for this preprint (which was not certified by peer review) is the author/funder, who has granted medRxiv a license to display the preprint in perpetuity.

It is made available under a CC-BY-NC 4.0 International license .

\section{Abstract}

\section{Importance}

The impact of the SARS-CoV-2 pandemic on children remains unclear. Better understanding of the burden of COVID-19 among children and their protection against re-infection is crucial as they will be among the last groups vaccinated.

\section{Objective}

To characterize the burden of COVID-19 and assess how protection from symptomatic re-infection among children may vary by age.

\section{Design}

A prospective, community-based pediatric cohort study conducted from March 1, 2020 through October 15, 2021.

\section{Setting}

The Nicaraguan Pediatric Influenza Cohort is a community-based cohort in District 2 of Managua, Nicaragua.

\section{Participants}

A total of 1964 children aged 0-14 years participated in the cohort. Non-immunocompromised children were enrolled by random selection from a previous pediatric influenza cohort. Additional newborn infants aged $\leq 4$ weeks were randomly selected and enrolled monthly, via home visits.

\section{Exposures}

Prior COVID-19 infection as confirmed by positive anti SARS-CoV-2 antibodies (receptor binding domain [RBD] and spike protein) or real time RT-PCR confirmed COVID-19 infection $\geq 60$ days prior to current COVID-19.

\section{Main Outcomes and Measures}

Symptomatic COVID-19 cases confirmed by real time RT-PCR and hospitalization within 28 days of symptom onset of confirmed COVID-19 case.

\section{Results}

Overall, $49.8 \%$ of children tested were seropositive over the course of the study. There were also 207 PCR-confirmed COVID-19 cases, 12 (6.4\%) of which were severe enough to require hospitalization. Incidence of COVID-19 was highest among children aged <2 years -16.1 per 100 person-years (95\% Confidence Interval $[\mathrm{Cl}]: 12.5,20.5)$-approximately three times that of children in any other age group assessed. Additionally, 41 (19.8\%) symptomatic SARS-CoV-2 episodes were re-infections, with younger children slightly more protected against symptomatic reinfection. Among children aged 6-59 months, protection was $61 \%$ (Rate Ratio [RR]:0.39, 95\% Cl:0.2,0.8), while protection among children aged 5-9 and $10-14$ years was $64 \%$ (RR:0.36,0.2,0.7), and $49 \%$ (RR:0.51,0.3-0.9), respectively.

\section{Conclusions and Relevance} In this prospective community-based pediatric cohort rates of symptomatic and severe COVID-19 were highest among the youngest participants, with rates stabilizing around age 5 . Reinfections represent a large proportion of PCR-positive cases, with children $<10$ years displaying greater protection from symptomatic reinfection. A vaccine for children $<5$ years is urgently needed. 
medRxiv preprint doi: https://doi.org/10.1101/2022.01.03.22268684; this version posted January 5, 2022. The copyright holder for this preprint (which was not certified by peer review) is the author/funder, who has granted medRxiv a license to display the preprint in perpetuity.

It is made available under a CC-BY-NC 4.0 International license .

82 The SARS-CoV-2 pandemic has resulted in severe disease and death globally, particularly among the

83 elderly and immunocompromised. ${ }^{1,2}$ Although most pediatric SARS-CoV-2 infections are mild or

84 asymptomatic, severe illness occurs in children, including typical severe respiratory infection and multi-

85 system inflammatory syndrome (MIS-C). ${ }^{3,4}$ Though less common than in adults, studies have suggested

86 that younger children, older adolescents, and children with underlying health conditions more

87 frequently present with symptomatic or severe COVID-19..$^{5-7}$ They may also be more likely to have post-

88 acute sequelae, often referred to as "long covid", though still less likely compared to adults. ${ }^{8,9}$ However,

89 most of the literature regarding the burden of SARS-CoV-2 in children comes from hospital-based

90 studies, which underestimate the disease burden in children-particularly those with mild

91 infections. ${ }^{4,6,10-14}$ Further, what pediatric community-level evidence does exist is largely from high-

92 income countries and includes few children $<5$ years. ${ }^{15-17}$ As such, despite understanding that differences

93 in infection severity exist between adults and children, the burden and characteristics of SARS-CoV-2

94 infection among children remain poorly characterized. ${ }^{3,18}$

96 Understanding the implications of SARS-CoV-2 for children is particularly important, as children will be

97 among the last to be vaccinated. At the time of writing, only one vaccine has been approved in the

98 United States and Europe for children under age $11^{19}$, and vaccine supplies for many countries-

99 particularly low- and middle-income countries (LMICs)-remain limited. ${ }^{20}$ In fact, as of November 12 ,

1002021 , only6.5\% of people in low-income countries have received at least one dose. ${ }^{20,21}$ However, even in

101 high-income countries where older children are already being vaccinated, it is critical that we

102 understand the natural history of SARS-CoV-2 in children.

103

104 As a consensus has grown around the likelihood of SARS-CoV-2 becoming endemic, researchers have

105 begun exploring what the transition to endemicity might look like so that interventions might be tailored 
medRxiv preprint doi: https://doi.org/10.1101/2022.01.03.22268684; this version posted January 5, 2022. The copyright holder for this preprint (which was not certified by peer review) is the author/funder, who has granted medRxiv a license to display the preprint in perpetuity.

It is made available under a CC-BY-NC 4.0 International license .

106

107

108

109

110

111

112

113

114

115

116

117

Parents agreed to bring their children to the study clinic (HCSFV) for any illness, and all participants were

to be more effective. The strength and durability of immune protection against SARS-CoV-2 is perhaps the most important factor in this consideration. A February 2021 study by Lavine et al. suggests that even though sterilizing immunity may wane quickly, if protection against severe infections remains relatively stable, SARS-CoV-2 may become no more severe than the known seasonal human coronaviruses. ${ }^{22}$ However, key uncertainties in the natural history of SARS-CoV-2 infection limit our ability to predict whether this will occur. Of particular importance is the strength and durability of immune protection against illness across the severity spectrum following natural infection in children and whether the increased circulation of variants of concern has impacted the severity of COVID-19 in children. These questions are also of great relevance to future emerging pathogens with pandemic potential. Using data from a community-based prospective pediatric cohort in Managua, Nicaragua, we aimed to assess the burden of infection and disease in the cohort, the strength of protection from symptomatic re-infection, and the relative severity of symptomatic re-infections.

\section{Methods}

\section{Ethics statement}

The study was approved by the Institutional Review Boards of the Nicaraguan Ministry of Health and the University of Michigan. Written informed consent was obtained from a parent/guardian of all participants, and verbal assent was obtained from children aged $\geq 6$ years.

\section{Study population and sample collection}

Participants were from the Nicaraguan Pediatric Influenza Cohort, the methods of which have been

described in detail previously. ${ }^{23}$ Briefly, children aged 0-14 years were enrolled when visiting the Health Center Sócrates Flores Vivas (HCSFV), or through home visits, and followed until their $15^{\text {th }}$ birthday or loss to follow-up. 
medRxiv preprint doi: https://doi.org/10.1101/2022.01.03.22268684; this version posted January 5, 2022. The copyright holder for this preprint (which was not certified by peer review) is the author/funder, who has granted medRxiv a license to display the preprint in perpetuity.

It is made available under a CC-BY-NC 4.0 International license .

collected from participants aged 2-14 years presenting with fever/parent-reported fever and at least 1 of the following: cough, sore throat, or rhinorrhea, while respiratory samples were collected from participants aged $<2$ years who presented with fever/parent-reported fever. However, in June 2020 these criteria were expanded so that samples were also collected from children presenting with loss of taste or smell, rash, conjunctivitis, or fever without a defined focus. Samples were collected using nasal and oropharyngeal flocked plastic swabs. Blood samples were obtained from children upon enrollment and yearly thereafter, in February/March 2020 and February/March 2021. A subset of children had an additional blood sample collected in September/October 2020.

\section{Laboratory methods}

RNA was extracted from respiratory samples (QIAamp Viral RNA Mini Kit, Qiagen) and tested for SARSCoV-2 via real time RT-PCR. ${ }^{24}$ Blood samples were tested for antibodies against the SARS-CoV-2 receptor-binding domain (RBD) and spike proteins via enzyme-linked immunosorbent assay (ELISA). ${ }^{25}$ Samples were tested for an endpoint using fourfold dilution from 100 until 6400, and the titer for each sample was obtained using the Reed and Muench method.

\section{Data collection and case definitions}

Yearly surveys were administered at the individual and household levels every March/April, collecting data on a wide variety of social and environmental factors. A SARS-CoV-2-specific survey was also completed in September/October 2020 and February/March 2021. Finally, comprehensive, systematic medical consult forms were collected upon each visit to the study health clinic. Data were also collected at follow-up visits that were conducted until the resolution of a child's illness.

We classified the severity of COVID-19 as: subclinical, mild, moderate, or severe. Participants who reported no symptoms associated with their infection were classified as subclinical. Those with any symptoms excluding difficulty breathing, rapid breathing, or shortness of breath were classified as mild. Moderate COVID-19 was considered illness with associated difficulty breathing, rapid breathing, or 
medRxiv preprint doi: https://doi.org/10.1101/2022.01.03.22268684; this version posted January 5, 2022. The copyright holder for this preprint (which was not certified by peer review) is the author/funder, who has granted medRxiv a license to display the preprint in perpetuity.

It is made available under a CC-BY-NC 4.0 International license . using $\mathrm{R}$ version 4.1.1.

\section{Results}


medRxiv preprint doi: https://doi.org/10.1101/2022.01.03.22268684; this version posted January 5, 2022. The copyright holder for this preprint (which was not certified by peer review) is the author/funder, who has granted medRxiv a license to display the preprint in perpetuity.

It is made available under a CC-BY-NC 4.0 International license .

Between March 1, 2020, and October 15, 2021, a total of 1964 children participated in the study, contributing a total of 2733.6 person years, an average of1.4 years per person (Table 1). One hundred and fifty-nine (8.1\%) children withdrew from the study or were lost to follow-up. The most common reasons for early withdrawal were failure to appear for their yearly annual sample $(44.0 \%)$ and inability to find the participant at home (27.7\%). Participants recorded 9804 visits to the health center with 1497 (76.2\%) children having at least one visit. In all, 1014 (51.6\%) participants were infected with SARS-CoV2 as determined by PCR or ELISA over the course of the study the study.

Incidence of PCR-confirmed COVID-19

Between March 1, 2020, and October 15, 2021, there were a total of 207 PCR-confirmed COVID-19 cases that occurred in 201 (10.2\%) participants (Table 2, Figure 1A). While low-level transmission occurred throughout the study, most cases occurred in two distinct waves: March-August 2020 and April-October 2021 (Figure 1A). The overall incidence rate of COVID-19 in the cohort was 7.7 cases per 100 personyears (95\% Confidence Interval $[\mathrm{Cl}]: 6.6,8.8)$. When examined by age, children $<2$ years had the greatest incidence of COVID-19, with 16.1 cases per 100 person-years ( $95 \% \mathrm{Cl}: 12.5,20.5)$ (Table 2, Figure 1B). Above age 2, the incidence of COVID-19 was substantially lower, but relatively stable, with rates of5.5 (95\% Cl:3.7,7.9),5.8 (95\% Cl:4.3,7.6), and6.9 (95\% Cl:5.3,8.9) cases per 100 person-years among children aged 2-4, 5-9, and 10-14 years, respectively (Table 2, Figure 1B). Female participants had a slightly higher incidence of COVID-19 when compared to males; however, the difference was not significant (Table 2).

\section{ELISA-confirmed symptomatic SARS-CoV-2 infection}

ELISA results for anti-SARS-CoV-2 antibodies were obtained for 1824 (92.9\%) of participants, with 908 (49.8\%) being seropositive over the course of the study. Antibody titers were obtained from 877 (96.6\%) of seropositive participants. Seroreversion was rare, with $11(1.2 \%)$ previously seropositive participants subsequently testing negative by ELISA. Of these, 10 (90.9\%) were $>5$ years of age, while 1 was $<6$ 
medRxiv preprint doi: https://doi.org/10.1101/2022.01.03.22268684; this version posted January 5, 2022. The copyright holder for this preprint (which was not certified by peer review) is the author/funder, who has granted medRxiv a license to display the preprint in perpetuity.

It is made available under a CC-BY-NC 4.0 International license .

202

203

204

205

206

207

208

209

210

211

212

213

214

215

216

217

218

219

220

221

222

223

224

225

months, suggesting that this represented a loss of maternal antibodies. Additionally, among children who seroreverted, only 2 had had illness episodes that were symptomatic (both were mild) -the rest were subclinical. Titers were highest among young children, decreasing between 4-6 years of age before reaching a plateau where they remained relatively stable (Figure $2 \mathrm{~A}$ ). We also saw evidence of relatively rapid waning of maternal antibodies among young infants, with titers steadily decreasing in the first 4 months of life before beginning to increase again (Figure 2B). We observed no meaningful difference in titers by sex (Supplemental Figure 1).

\section{COVID-19 severity}

Among PCR-confirmed COVID-19 cases, 12 (5.8\%) required hospitalization, resulting in an incidence rate of0.4 (95\% Cl:0.2,0.8) per 100 person years (Supplemental Table 1). Children aged <2 years had the highest rate of hospitalization associated with COVID-19-2.8 times that of children aged 2-4 years and8.5 times that of children aged 5-9 years (Supplemental Table 1, Supplemental Figure 2A). We did not observe any children aged 10-14 years with COVID-19 who required hospitalization.

\section{Clinical presentation and long COVID}

Children with PCR-confirmed COVID-19 presented with a variety of symptoms, with runny nose (75\%), cough (71\%), and fever/feverishness (67\%) being the most common (Supplemental Table 2,

Supplemental Figure 2). While symptoms resolved within four weeks for most children with PCRconfirmed infections, $21(10.4 \%)$ participants had at least one symptom that was present $\geq 28$ days after symptom onset and were classified as having "long COVID". Of these, $9(13.6 \%)$ were <2 years, 2 (6.7\%) were $2-4$ years old, 3 (5.8\%) were 5-9 years old, and 7 (11.9\%) were $10-14$ years old. Most participants with long COVID had upper respiratory symptoms that lasted 28 days or longer (14 with runny nose, 7 with cough, 3 with sore throat, and 3 with nasal congestion), while few had long-duration non-specific symptoms ( 4 still had a fever and 5 still had a headache). One participant under 2 years old still had diarrhea and another under 2 years had rapid breathing. 
medRxiv preprint doi: https://doi.org/10.1101/2022.01.03.22268684; this version posted January 5, 2022. The copyright holder for this preprint (which was not certified by peer review) is the author/funder, who has granted medRxiv a license to display the preprint in perpetuity.

It is made available under a CC-BY-NC 4.0 International license .

\section{Protection from symptomatic second SARS-CoV-2 infection}

Symptomatic re-infection with SARS-CoV-2 was relatively common in the cohort, with 41 (19.8\%) PCRconfirmed episodes occurring in children with previous SARS-CoV-2 infection detected by PCR or ELISA. All second infections occurred in 2021 when variants of concern, particularly gamma and delta, began actively circulating in Nicaragua. ${ }^{28}$ The relative rate of symptomatic second infection followed a similar pattern to that observed with all COVID-19 cases and associated severe presentations such as hospitalization. Children aged 6 months to 4 years and 5-9 years displayed slightly higher protection from symptomatic second infection at $61 \%$ (RR:0.39, 95\% $\mathrm{Cl}: 0.2,0.8$ ) and $64 \%$ (RR:0.36, 95\% $\mathrm{Cl}: 0.2,0.7$ ) respectively, compared to $49 \%$ (RR:0.51, 95\% $\mathrm{Cl}: 0.3,0.9$ ) among children 10-14 years (Table 3, Figure 1C). Children under 6 months of age at ELISA testing were excluded from the above analysis as they may still have maternal antibody present and thus are not necessarily reinfections. This is consistent with what we observed with antibody titers in the first year of life with a steady decrease in titers in the first six months followed by an increase from 6-12 months (Figure 2B). While moderate and severe secondary cases of COVID-19 did occur, we did not detect any difference in severity between first and second infections (Supplemental Table 3).

\section{Discussion}

In this analysis, we assessed the incidence and severity of SARS-CoV-2 infections, as well as protection from symptomatic re-infection, within a prospective, community-based cohort of Nicaraguan children. We observed high rates of infection, with $51.6 \%$ of children being infected over the course of the study. While the majority of SARS-CoV-2 episodes were mild or subclinical (Supplemental Table 4), severe illness requiring hospitalization did occur, particularly among children $<2$ years (Supplemental Table 1). Symptomatic re-infection with SARS-CoV-2 was also common, with $19.8 \%$ of PCR-confirmed episodes of SARS-CoV-2 being second infections. This contributed to the lower levels of protection against symptomatic re-infection that we observed compared to previous studies. 
medRxiv preprint doi: https://doi.org/10.1101/2022.01.03.22268684; this version posted January 5, 2022. The copyright holder for this preprint (which was not certified by peer review) is the author/funder, who has granted medRxiv a license to display the preprint in perpetuity.

It is made available under a CC-BY-NC 4.0 International license .

252 Our findings regarding the relative frequency and severity of COVID-19 in children are consistent with

253 those in the literature-specifically that pediatric SARS-CoV-2 infections are common but are largely

254 mild or subclinical..$^{5-7}$ Another study in Nicaragua reported that $37.7 \%$ of children aged $<15$ were

255 seropositive for SARS-CoV-2, substantially lower than the $49.8 \%$ we observed in our study. ${ }^{29}$ It was,

256 however, consistent with that estimated from a previously published analysis in a household

257 transmission cohort in the same community where $56.7 \%$ of participants were infected. ${ }^{30}$ While over

$25850 \%$ of the cohort were infected in the course of the study, only $207(19.6 \%)$ cases were detected by

259 PCR. This again demonstrates that COVID-19 cases make up only a small proportion of infections in

260 children, and underscores the importance of community-based, prospective studies in accurately

261 characterizing the natural history of pediatric SARS-CoV-2 infection. Previous studies have also indicated

262 that while most children with symptomatic infections observe symptom resolution within a few weeks,

263 some children do experience sustained symptoms broadly described as "long COVID". 9,15 Among

children with symptomatic SARS-CoV-2 infection, we observed 21 (10.1\%) with symptoms that were

present $\geq 28$ days after symptom onset, a larger proportion than the $4.4 \%$ reported by Molteni et al. ${ }^{15}$

However, this difference can likely be attributed to their not including children aged $<5$ years, as the

272 Given the frequently mild presentation of pediatric SARS-CoV-2 infections, the relative dearth of

273 community-based cohort studies of SARS-CoV-2 infection in children has resulted in a poor

274 understanding of the protection following infection. A previous study in this same community found 
medRxiv preprint doi: https://doi.org/10.1101/2022.01.03.22268684; this version posted January 5, 2022. The copyright holder for this preprint (which was not certified by peer review) is the author/funder, who has granted medRxiv a license to display the preprint in perpetuity.

It is made available under a CC-BY-NC 4.0 International license .

275 that protection following infection was similar to that afforded by vaccines ${ }^{30}$; however, this was before

276 variants of concern were widely circulating in Nicaragua and was not powered to assess protection

277 among children under 5 . Here, we found that symptomatic second infections were quite common,

278 making up $20 \%$ of all PCR-confirmed episodes of symptomatic SARS-CoV-2 infection, with children 6-59

279 months and 5-9 years displaying greater protection against symptomatic second infection (Table 3,

280 Figure 1C). Notably, some of these second infections resulted in illnesses classified as moderate or

281 severe. We were underpowered to sufficiently explore severity of second infections compared to first.

282 Given its implications for pediatric vaccination strategies, the relative severity of second SARS-CoV-2

283 infections in children should be monitored closely moving forward. ${ }^{22}$

This study has several key strengths. First, as a prospective, community-based pediatric cohort, it

provides valuable insight into the burden of symptomatic SARS-CoV-2 infection within a population that

287 is likely to be among the last to be vaccinated-children in low- and middle-income countries. Second,

by utilizing well-established systems for sample collection/testing combined with robust data collection,

we were able to characterize key aspects of SARS-CoV-2 presentation and severity among children that

remain poorly described. Third, by incorporating serologic testing and genetic sequencing, we were able

296 This analysis does have several limitations. First, the initial serology samples were collected in

297 February/March 2020-largely before the first wave of SARS-CoV-2 infections in Nicaragua. As such, it is 
medRxiv preprint doi: https://doi.org/10.1101/2022.01.03.22268684; this version posted January 5, 2022. The copyright holder for this preprint (which was not certified by peer review) is the author/funder, who has granted medRxiv a license to display the preprint in perpetuity. It is made available under a CC-BY-NC 4.0 International license.

most of these infections were captured via PCR or by ELISA testing of samples collected in late 2020 and early 2021. Additionally, to assess illness severity of infections detected only by ELISA, we relied on retrospective surveys that may have been subject to recall bias. Fortunately, this is likely to have affected only the mildest of cases as the PCR testing criteria were quite broad-particularly after being expanded in June 2020. Finally, as a community-based, prospective cohort study, we were underpowered to assess the burden of MIS-C and death associated with SARS-CoV- 2 infection due to their rarity.

Through this prospective cohort of Nicaraguan children, we were able to assess the impact of SARS-CoV2 infection on children aged 0-14 years at the community level. We observed high rates of infection, with $51.6 \%$ of children having been infected with SARS-CoV-2 over the course of the study. While illness was generally mild, severe illness and prolonged sequelae were observed-most often among children 
medRxiv preprint doi: https://doi.org/10.1101/2022.01.03.22268684; this version posted January 5, 2022. The copyright holder for this preprint (which was not certified by peer review) is the author/funder, who has granted medRxiv a license to display the preprint in perpetuity.

It is made available under a CC-BY-NC 4.0 International license .

\section{References}

1. O'Driscoll M, Ribeiro Dos Santos G, Wang L, et al. Age-specific mortality and immunity patterns of SARS-CoV-2. Nature. 2021;590(7844):140-145.

2. Parohan $M$, Yaghoubi S, Seraji A, Javanbakht $M H$, Sarraf $P$, Djalali M. Risk factors for mortality in patients with Coronavirus disease 2019 (COVID-19) infection: a systematic review and metaanalysis of observational studies. Aging Male. 2020;23(5):1416-1424.

3. Bhuiyan MU, Stiboy E, Hassan MZ, et al. Epidemiology of COVID-19 infection in young children under five years: A systematic review and meta-analysis. Vaccine. 2021;39(4):667-677.

4. Parcha V, Booker KS, Kalra R, et al. A retrospective cohort study of 12,306 pediatric COVID-19 patients in the United States. Sci Rep. 2021;11(1):10231.

5. Kufa T, Jassat W, Cohen C, et al. Epidemiology of SARS-CoV-2 infection and SARS-CoV-2 positive hospital admissions among children in South Africa. Influenza Other Respir Viruses. 2021.

6. Bailey LC, Razzaghi H, Burrows EK, et al. Assessment of 135794 Pediatric Patients Tested for Severe Acute Respiratory Syndrome Coronavirus 2 Across the United States. JAMA Pediatr. 2021;175(2):176-184.

7. Bolaños-Almeida CE, Espitia Segura OM. Clinical and Epidemiologic Analysis of COVID-19 Children Cases in Colombia PEDIACOVID. Pediatr Infect Dis J. 2021;40(1):e7-e11.

8. Smane L, Roge I, Pucuka Z, Pavare J. Clinical features of pediatric post-acute COVID-19: a descriptive retrospective follow-up study. Ital J Pediatr. 2021;47(1):177.

9. Brackel CLH, Lap CR, Buddingh EP, et al. Pediatric long-COVID: An overlooked phenomenon? Pediatr Pulmonol. 2021;56(8):2495-2502.

10. Götzinger F, Santiago-García B, Noguera-Julián A, et al. COVID-19 in children and adolescents in Europe: a multinational, multicentre cohort study. Lancet Child Adolesc Health. 2020;4(9):653661.

11. Loomba RS, Villarreal EG, Farias JS, Bronicki RA, Flores S. Pediatric Intensive Care Unit Admissions for COVID-19: Insights Using State-Level Data. Int J Pediatr. 2020;2020:9680905.

12. Salako A, Odubela O, Musari-Martins T, et al. Prevalence and Presentation of Paediatric Coronavirus Disease 2019 in Lagos, Nigeria. Int J Pediatr. 2021;2021:2185161.

13. Saleh NY, Aboelghar HM, Salem SS, et al. The severity and atypical presentations of COVID-19 infection in pediatrics. BMC Pediatr. 2021;21(1):144.

14. Somekh I, Stein M, Karakis I, Simões EAF, Somekh E. Characteristics of SARS-CoV-2 Infections in Israeli Children During the Circulation of Different SARS-CoV-2 Variants. JAMA Netw Open. 2021;4(9):e2124343.

15. Molteni $\mathrm{E}$, Sudre $\mathrm{CH}$, Canas $\mathrm{LS}$, et al. Illness duration and symptom profile in symptomatic UK school-aged children tested for SARS-CoV-2. Lancet Child Adolesc Health. 2021;5(10):708-718.

16. Waterfield T, Watson C, Moore R, et al. Seroprevalence of SARS-CoV-2 antibodies in children: a prospective multicentre cohort study. Arch Dis Child. 2021;106(7):680-686.

17. Watson AM, Haraldsdottir K, Biese KM, Goodavish L, Stevens B, McGuine TA. COVID-19 in US Youth Soccer Athletes During Summer 2020. J Athl Train. 2021;56(6):542-547.

18. Wiedenmann M, Goutaki M, Keiser O, Stringhini S, Tanner M, Low N. The role of children and adolescents in the SARS-CoV-2 pandemic: a rapid review. Swiss Med Wkly. 2021;151:w30058.

19. Pfizer B. Pfizer and BioNTech Announce Positive Topline Results From Pivotal Trial of COVID-19 Vaccine in Children 5 to 11 Years. https://www.businesswire.com/news/home/20210920005452/en/. Updated 9/20/2021. Accessed 11/7/2021.

20. Hannah Ritchie EM, Lucas Rodés-Guirao, Cameron Appel, Charlie Giattino, Esteban Ortiz-Ospina, Joe Hasell, Bobbie Macdonald, Diana Beltekian and Max Roser. Coronavirus Pandemic (COVID19). Our World in Data. 2020. 
medRxiv preprint doi: https://doi.org/10.1101/2022.01.03.22268684; this version posted January 5, 2022. The copyright holder for this preprint (which was not certified by peer review) is the author/funder, who has granted medRxiv a license to display the preprint in perpetuity.

It is made available under a CC-BY-NC 4.0 International license .

21. UNDP. Global Dashboard of Vaccine Equity. https://data.undp.org/vaccine-equity/. Published 2021. Accessed 11/1/2021.

22. Lavine JS, Bjornstad ON, Antia R. Immunological characteristics govern the transition of COVID19 to endemicity. Science. 2021;371(6530):741-745.

23. Gordon A, Kuan G, Aviles W, et al. The Nicaraguan pediatric influenza cohort study: design, methods, use of technology, and compliance. BMC Infect Dis. 2015;15:504.

24. Chu DKW, Pan Y, Cheng SMS, et al. Molecular Diagnosis of a Novel Coronavirus (2019-nCoV)

25. Amanat F, Stadlbauer D, Strohmeier S, et al. A serological assay to detect SARS-CoV-2 seroconversion in humans. medRxiv. 2020.

26. Stevenson M, Nunes T, Sanchez J, et al. EpiR: An R package for the analysis of epidemiological data. 2013:9-43.

27. Ulm K. A simple method to calculate the confidence interval of a standardized mortality ratio (SMR). Am J Epidemiol. 1990;131(2):373-375.

28. Maier HE, Balmaseda A, Ojeda S, et al. An immune correlate of SARS-CoV-2 infection and severity of reinfections. medRxiv. 2021.

29. González F, Vielot NA, Sciaudone M, et al. Seroepidemiology of SARS-CoV-2 infections in an urban Nicaraguan population. medRxiv. 2021.

30. Maier HE, Kuan G, Saborio S, et al. Clinical spectrum of SARS-CoV-2 infection and protection from symptomatic re-infection. Clin Infect Dis. 2021. 
medRxiv preprint doi: https://doi.org/10.1101/2022.01.03.22268684; this version posted January 5, 2022. The copyright holder for this preprint (which was not certified by peer review) is the author/funder, who has granted medRxiv a license to display the preprint in perpetuity.

It is made available under a CC-BY-NC 4.0 International license .

\section{Contributions}

386 JTK led the analysis and drafted the manuscript. AB conducted the cohort study and coordinated the

387 molecular and serological testing. GK conducted the cohort study. AG is the Principal Investigator for the

388 Nicaraguan Pediatric Influenza Cohort Study and conceptualized the cohort study and analysis. AMF

389 contributed to the analysis and the drafting/revision of the manuscript. All authors contributed to the

390 manuscript and its revision and approved its submission.

\section{Data Sharing}

392 Individual-level data may be shared with outside investigators following University of Michigan IRB approval. R code is available on GitHub (https://github.com/jkubale). Please contact Aubree Gordon

394 (gordonal@umich.edu) to arrange for data access.

\section{Conflicts of Interest}

Aubree Gordon serves on an RSV vaccine scientific advisory board for Janssen Pharmaceuticals and has served on a COVID-19 scientific advisory board for Gilead Sciences. All other authors certify no potential conflicts of interests.

\section{Acknowledgements}

400 This work was supported by the National Institute for Allergy and Infectious Diseases (NIAID) at the US

401 National Institutes of Health (grant U01AI088654 and contract HHSN272201400006C) and a grant from

402 Open Philanthropy. We would also like to thank the study participants and their families, the amazing

403 study staff, and the people of Nicaragua. Without them none of this would be possible. We would like to 404 thank Leo Poon for providing the protocol and controls for RT-PCR testing, and Florian Krammer for 405 sharing RBD and Spike constructs as well as technical advice. We are grateful to Janet Smith, Melanie 406 Ohi and their groups at the Center of Structural Biology at the UM Life Sciences Institute for producing 407 proteins and antibodies for the ELISAs. 
medRxiv preprint doi: https://doi.org/10.1101/2022.01.03.22268684; this version posted January 5, 2022. The copyright holder for this preprint (which was not certified by peer review) is the author/funder, who has granted medRxiv a license to display the preprint in perpetuity. It is made available under a CC-BY-NC 4.0 International license.

Tables:

410

Table 1: Characteristics of study participants

411

\section{Male $^{\mathrm{a}}$ \\ Age $^{b}$}

Characteristic

Time in study (person-years) ${ }^{b}$

Water tap outside house ${ }^{a}(n=1716)$

Number in household ${ }^{b}(n=1716)$

${ }^{\mathrm{a}} \mathrm{N}(\%)$

${ }^{b}$ Mean(std. dev)
412

413

414

415

\begin{tabular}{|c|c|c|c|}
\hline \multicolumn{2}{|c|}{ Characteristic } & $\mathbf{N}=\mathbf{2 0 7 ^ { a }}$ & Incidence Rate per 100 person-years \\
\hline \multicolumn{2}{|c|}{ Male } & $93(44.9)$ & $6.8(5.6,8.4)$ \\
\hline \multicolumn{2}{|c|}{ Female } & $114(55.1)$ & $8.4(7.0,10.1)$ \\
\hline \multirow[t]{4}{*}{$\mathrm{Ag}$} & $<2$ years & $66(31.9)$ & $16.1(12.5,20.5)$ \\
\hline & $2-4$ years & $30(14.5)$ & $5.5(3.7,7.9)$ \\
\hline & $5-9$ years & $52(25.1)$ & $5.8(4.3,7.6)$ \\
\hline & $10-14$ years & $59(28.5)$ & $6.9(5.3,8.9)$ \\
\hline \multicolumn{4}{|c|}{${ }^{\mathrm{a}} \mathrm{N}(\%)$} \\
\hline
\end{tabular}

Table 2: Incidence of Symptomatic SARS-CoV-2
$\mathrm{N}=1964$

$985(50.2 \%)$

$6.9(4.4)$

$1.4(0.4)$

$584(34.0)$

$7.9(4.4)$ 
medRxiv preprint doi: https://doi.org/10.1101/2022.01.03.22268684; this version posted January 5, 2022. The copyright holder for this preprint (which was not certified by peer review) is the author/funder, who has granted medRxiv a license to display the preprint in perpetuity. It is made available under a CC-BY-NC 4.0 International license .

\begin{tabular}{|c|c|c|c|}
\hline Characteristic & & $\begin{array}{l}\text { Number of second } \\
\text { infections }(\mathrm{N}=41)^{\mathrm{a}}\end{array}$ & Protection $^{b}$ \\
\hline Male & & $14(34.1)$ & $62 \%$ (RR: $0.38,95 \% \mathrm{Cl}: 0.2,0.7$ ) \\
\hline Female & & $27(65.9)$ & $55 \%$ (RR: $0.45,95 \% \mathrm{Cl}: 0.3,0.7$ ) \\
\hline \multirow[t]{3}{*}{ Age } & $6-59$ months & $10(24.4)$ & $61 \%$ (RR: $0.39,95 \% \mathrm{Cl}: 0.2,0.8$ ) \\
\hline & $5-9$ years & $11(26.8)$ & 64\% (RR: $0.36 ; 95 \% \mathrm{Cl}: 0.2,0.7$ ) \\
\hline & $10-14$ years & $20(48.8)$ & 49\% (RR: $0.51 ; 95 \% \mathrm{Cl}: 0.3,0.9$ ) \\
\hline $\begin{array}{l}{ }^{\mathrm{a}} \mathrm{N}(\%) \\
{ }^{\mathrm{b}} \text { Protection cal }\end{array}$ & as $1-R R$ & & \\
\hline
\end{tabular}

425

426 
medRxiv preprint doi: https://doi.org/10.1101/2022.01.03.22268684; this version posted January 5, 2022. The copyright holder for this preprint (which was not certified by peer review) is the author/funder, who has granted medRxiv a license to display the preprint in perpetuity.

Figures:

Figure 1: A) PCR confirmed first and second cases by week over time. B) Incidence rate (per 100 person years) of PCR-confirmed symptomatic SARS-CoV-2 by Age - 95\% confidence intervals obtained using a intervals obtained using a Poisson distribution.

A
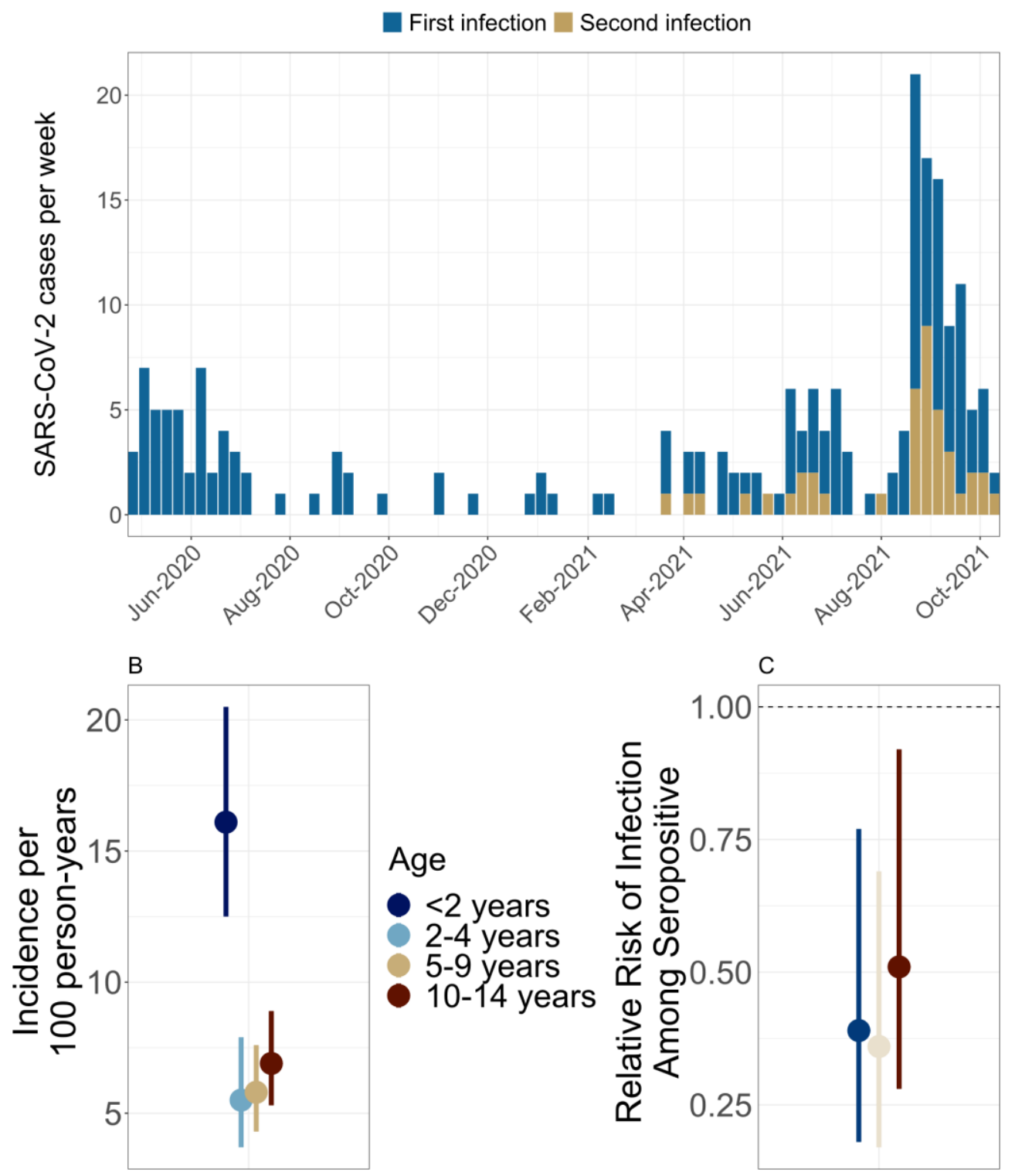

Age

6-59 months 5-9 years 10-14 years 
medRxiv preprint doi: https://doi.org/10.1101/2022.01.03.22268684; this version posted January 5, 2022. The copyright holder for this preprint (which was not certified by peer review) is the author/funder, who has granted medRxiv a license to display the preprint in perpetuity. It is made available under a CC-BY-NC 4.0 International license .

Figure 2: Anti SARS-CoV-2 IgG titers by age - Panel A shows the log IgG titers of participants by age with

434 a loess smoother and 95\% confidence interval to show the overall trend. Panel B shows the exploded
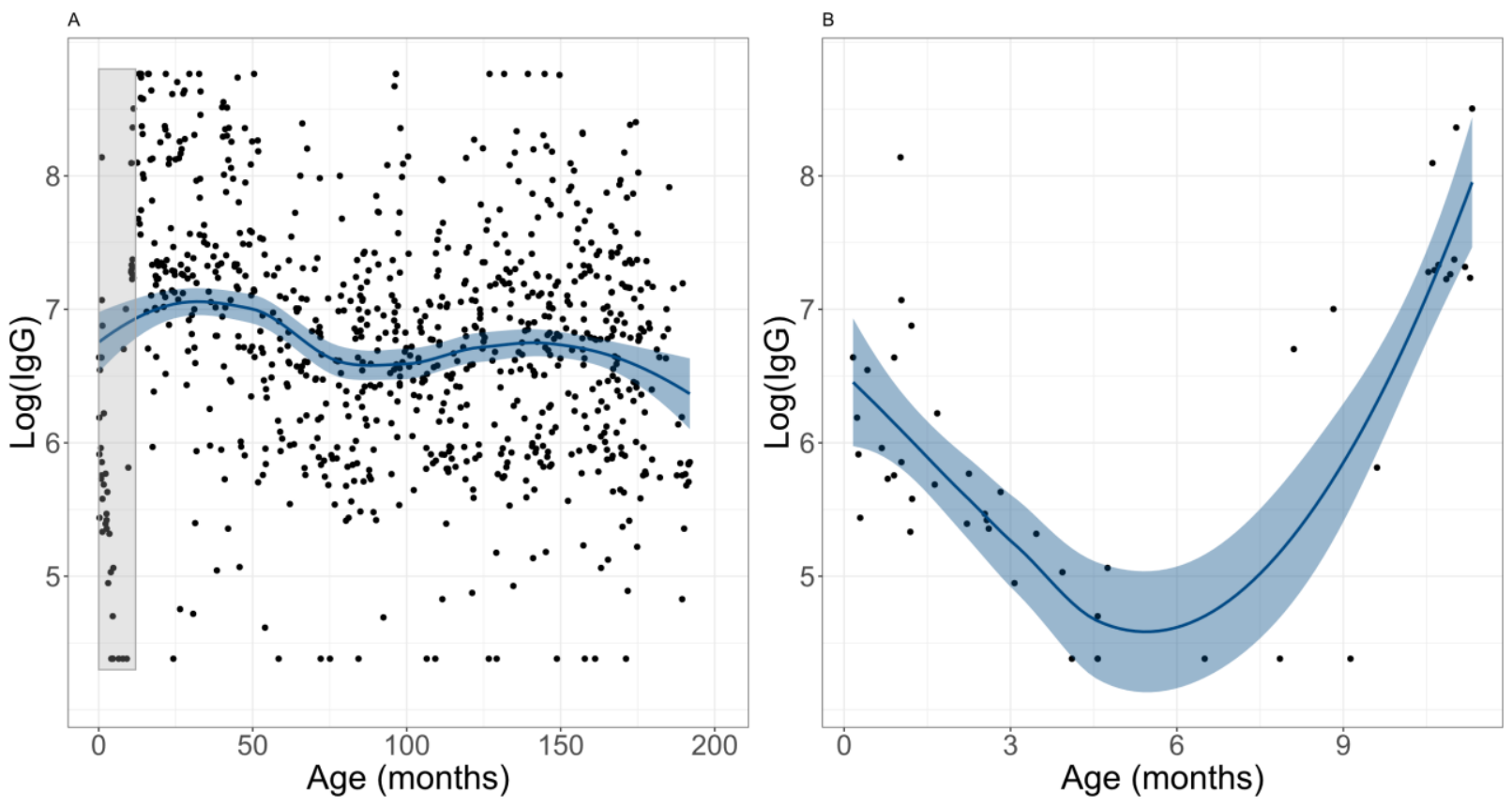